\title{
Moral Cognition in Criminal Punishment
}

\author{
Jason R. Steffen*
}

\begin{abstract}
Scholars often appeal to Kant in defending a retributivist view of criminal punishment. In this paper, I join other scholars in rejecting this interpretation as insufficiently attentive to Kant's wider theory of justice, particularly as found in the Rechtslehre, a section of the Metaphysics of Morals. I then turn to the Tugendlehre, where I examine analogies between Kant's treatments of morality and justice. In particular, I argue that Kant's own views about conscience and moral cognition should cause us to rethink the importance of lex talionis (an integral retributive principle) in the criminal justice system, and to adopt a more merciful attitude toward punishable criminals than we might otherwise be inclined to do. I end with a few policy proposals aimed at encouraging such moral cognition in contemporary AngloAmerican criminal justice systems
\end{abstract}

\section{KEYWORDS}

Punishment, Kant, Freedom, Virtue, Lex Talionis

\section{CONTENTS}

I. Kantian Punishment: ThreE INTERPREtATIONS..............................144

A. The Traditional View: Kant qua Retributivist ..............................145

B. An Alternate View: Kant qua Mixed Theorist.................................147

C. A Third Way: Punishment as a Requirement of Civic Freedom ....151

D. Objections to the Preceding Interpretation.....................................157

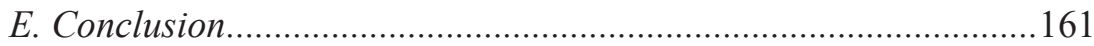

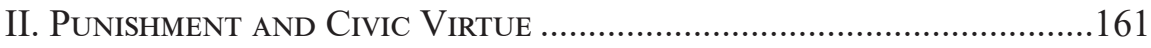

A. The Duties of Conscience and Moral Cognition.............................161

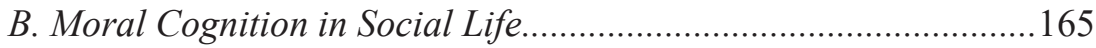

C. Moral Cognition in Criminal Punishment ....................................168

III. Specific Proposals for Moral Cognition in Punishment.............170

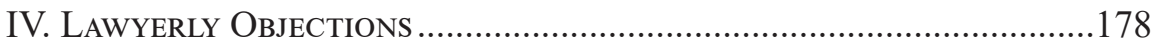

Assistant Public Defender, State of Minnesota Board of Public Defense; and Adjunct Professor, Mitchell Hamline School of Law 
The purpose of this paper is to advance a new understanding of Immanuel Kant's view of punishment which will, in turn, cause us to reevaluate our penal practices. One might be skeptical of the possibility of saying anything new in this area, as much ink has been spilled about punishment generally and, more specifically, punishment from a Kantian perspective. I aim to show, however, that the traditional interpretations of Kantian punishment are problematic - and that a more compelling interpretation should cause us to embrace fairer practices in the criminal justice system.

I shall therefore begin by addressing (in $\S \mathrm{I}$ ) two popular, competing views of Kantian punishment. I shall argue that both suffer from various deficiencies that should lead us to search for an alternative view. I shall then offer, as a third possibility, an interpretation of Kantian punishment that builds on Kant's view of civic freedom. Following this (in §II) I shall argue that a Kantian account of civic virtue should cause us to modify Kant's theory of punishment in an important way. Finally (in §III) I shall give several examples of what punishment would look like in a criminal justice system devoted to Kantian ideals.

\section{Kantian Punishment: Three Interpretations}

In debates over the ethical permissibility of punishment, scholars often cite Kant as the paradigmatic example of a retributivist. ${ }^{1}$ Such a characterization is hardly surprising; after all, Kant himself claims that "only the law of retribution . . . can specify definitely the quality and the quantity of punishment." ${ }^{.2}$ The retributivist interpretation is also supported by Kant's uncompromising stance on capital punishment: if someone "has committed murder he must die. Here there is no substitute that will satisfy justice."3

As facially compelling as the retributivist interpretation may be, however, some scholars have taken Kant's punishment theory to be a "mixed" or "hybrid" account. On this view, retributivism only partially grounds punishment, but relies on utilitarianism for justificatory completeness. ${ }^{4} \mathrm{~A}$ third approach is to examine Kant's wider theory of justice in order to discover the foundational principles underlying his discussion of punishment. My aim in this section is to show that the justice-based interpretation provides the most compelling account of Kantian punishment.

\footnotetext{
See, e.g., Jeffrie Murphy, Introduction, in Punishment and Rehabilitation 2, 1 (Jeffrie Murphy ed., 1995); Thomas E. Hill, Jr., Punishment, Conscience, and Moral Worth, in Kant's Metaphysics of Morals: Interpretive Essays 233. 233(Mark Timmons ed., 2002); Don E. Scheid, Kant's Retributivism, 93 Eтнics 265 n.8, 262(1983).

2 Immanuel Kant, The Metaphysics of Morals 105 (Mary Gregor, trans., Cambridge Univ. Press, 1996) (6:332). (Here and in subsequent footnotes, I put the standard Akademie pagination in parentheses after the regular citation.).

$3 \quad I d$. at $106(6: 333)$.

4 See generally, B. Sharon Byrd, Kant's Theory of Punishment: Deterrence in Its Threat, Retribution in Its Execution, 8 L. \& PHIL. 151 (1989) and Scheid, supra note 1, at 262.
} 


\section{A. The TRADitional VIEW: Kant qua RETRIBUtiVIST}

An initially plausible interpretation of Kant's justification for the imposition of criminal punishment is straightforwardly retributive: the government can and must punish criminals because (and only because) they have committed a particular kind of wrong - that is, one which violates the Universal Principle of Right (UPR).

In the Rechtslehre, the section of Kant's Metaphysics of Morals concerned with matters of justice, the UPR is given as the standard against which we can measure our social progress toward justice. It is a "universal criterion" we can use to determine whether an act is just or unjust, and it (similarly to the Categorical Imperative proposed in the more well-known Groundwork of the Metaphysics of Morals) is cognizable "in reason alone." In other words, Kant believes we will naturally arrive at the UPR if we think about what it means to act justly or unjustly. Succinctly stated, the UPR holds that "[a]ny action is right if it can coexist with everyone's freedom in accordance with a universal law, or if on its maxim the freedom of choice of each can coexist with everyone's freedom in accordance with a universal law."

Kant thinks that if we affirm the UPR (which we must if we are to have a just social order) then we will agree that "whatever is wrong is a hindrance to freedom in accordance with universal laws." If someone violates the UPR by taking an action that limits another person's freedom, then the State may properly use coercive force against the violator. The use of such coercion is admittedly "a hindrance to freedom," but it is one that is justified because it is limiting the freedom of somebody who has chosen to act contrary to the principle on which the just State is founded.

To give a simple example, the UPR would require that I refrain from kidnapping a fellow citizen - a very obvious deprivation of that person's freedom. If I were to kidnap someone, however, the State could justifiably imprison me-an equally clear deprivation of my freedom. Imprisoning citizens would normally be unjustified: the ruling party cannot simply imprison opposition leaders on a whim, because this would violate the UPR. But imprisoning me after I have violated the UPR is consistent with the UPR.

On this view, punishment is a moral obligation, not merely a facultative policy option at the state's disposal. The State may not consider another rationale for punishment: it "can never be inflicted merely as a means to promote some other good for the criminal himself or for civil society. It must always be inflicted upon him only because he has committed a crime." eliminate both rehabilitation ("some other good for the criminal himself") and even deterrence or incapacitation ("some other good ... for civil society") as justifiable grounds for criminal punishment.

Furthermore, once punishment has been found to be warranted on retributivist grounds, the "quality and quantity" of punishment must also be determined by the "law of retribution" or lex talionis: ${ }^{9}$ the punishment must be coextensive with the

\footnotetext{
KANT, supra note 2, at 23 (6:230).

Id. at $24(6: 231)$.

Id. at $25(6: 231)$.

Id. at 105 (6:331) (emphasis in original).

$I d$. at 105 (6:332). Kant uses the term jus in place of lex, and this may be the most appropriate word: jus properly refers to "law in the abstract" or a "legal right, power, or principle,"
} 
crime, as in the proverbial "eye for an eye." 10 So it would appear that not only can punishment not be imposed for reasons other than retribution, but the nature and extent of the punishment must also be determined by "pure and strict" retributivist principles. ${ }^{11}$

One of the common passages used to support the retributivist interpretation is where Kant avers that one who murders another must be put to death in order to satisfy the law of retribution, and any lesser punishment for any reason would be a "public violation of justice." 12 A sentencing judge could apparently not consider, for example, the murderer's age or criminal history, the circumstances of the crime or relationship of criminal and victim, and so forth. The law is clear: "If . . he has committed murder he must die."13 On the retributivist interpretation, similar propositions must hold for other types of crimes - for example, if someone maims another's arm, her body must be wounded to the same extent. ${ }^{14}$

Although facially plausible, there is a rather significant problem with interpreting Kant as a retributivist simpliciter: the passages used to justify the retributivist interpretation are contradicted by other passages, sometimes on the same page of text. For example, although Kant says that punishment must be meted out only "because [the criminal] has committed a crime," he also seems frequently to refer to deterrence or rehabilitation as goals of criminal punishment. Thus he says that the State may properly "draw[] from [the criminal's] punishment something of use for himself or his fellow citizens," which sounds suspiciously like rehabilitation (something of use for the criminal) and general deterrence (something of use for fellow citizens). ${ }^{15}$ This passage is prefaced by the statement that the criminal "must previously have been found punishable before any thought can be given" to these objectives, but it is not clear that being punishable necessarily entails a retributivist reason therefore. ${ }^{16}$ The retributivist might argue that Kant intends to relegate these alternative policy goals to secondary considerations: we have determined that the defendant must be executed for murder, but we are now free to consider how to execute him in order to, for example, maximize general deterrence (e.g. publicly, on prime-time television). This, though, seems an unsatisfactory, ad hoc resolution to the "apparent incompatibility" between these various passages. ${ }^{17}$ The retributivist is committed to saying that Kant is rather sloppily inconsistent. ${ }^{18}$ We should, however, entertain the possibility of a more charitable interpretation.

while lex is technically reserved for "[p]ositive law," or even "a statute." BLACK's LAW DictionARY, s.v. "jus" and "lex." However, this technical distinction is not well maintained in Anglo-American legal scholarship, which tends to use "lex" in this context.

does grant that, for certain types of crimes, it is not possible, or morally permissible, to punish the criminal by doing to her exactly what she has done to the victim. Id. at 130 (6:363). In such a case, a reasonable substitute punishment may be imposed. For example, the rapist is not to be raped, but castrated, $i d$., and the thief may be sentenced to "convict or prison labor." Id. at 106 (6:333).

5 Id. at $105(6: 331)$.

16 Id.

17 Scheid, supra note 1, at 265.

18 Thomas E. Hill Jr., Kant on Wrongdoing, Desert, and Punishment, 18 L. \& PHIL. 412 (1999). 
Another textual oddity bears particular mention. Kant explicitly approves of non-punishment in cases of what he terms "necessity"-for example, where the drowning man kills another in order to save his own life. ${ }^{19}$ Kant explains that we should excuse the killer, not because the killing is morally justifiable, but because "[a] penal law of this sort could not have the effect intended"; nobody would be deterred by the threat of death in the far future when she is facing the immediate prospect of death "that is certain (drowning)." 20

A retributivist adhering to lex talionis would have to say that the drowning offender should be put to death. We might, more commonly, be inclined to say that the person in this case has an excuse for his wrongdoing: perhaps it was wrong to kill the victim, but we can understand why one might do so in order to save one's own life. Finally, we might think that what the killer did was wrong and inexcusable, but was not murder-perhaps it was manslaughter or some kind of lesser crime. These latter two cases might be compatible with (a weaker form of) retributivism, though not with lex talionis. Still, Kant does not appear to give any of these explanations. Instead, he takes the death penalty off the table for what appear to be purely utilitarian reasons: because the goal of deterrence would be fruitless in such a case. If the retributivist interpretation of Kant's penal theory is correct, then the section on "necessity" is mistaken: Kant neglected to follow his own reasoning to its logical conclusion in this particular case.

In summary, aside from the obvious point that goals such as deterrence and incapacitation are intuitively reasonable ones that Kant likely would have included in his theory (as he explicitly does in the necessity case), the retributivist's main problem is reconciling the clearly retributive-sounding passages in the Rechtslehre with other, equally clearly non-retributive-sounding ones. These do not exhaust the potential worries we might have about retributivism generally, or even about a retributivist interpretation of Kant ${ }^{21}$, but they certainly suffice to cast doubt on such an interpretation. We shall therefore turn our attention to a second possible way of interpreting Kant's penal theory.

\section{B. An Alternate VieW: Kant qua MiXed Theorist}

Legal and moral philosophers have proposed various versions of "mixed" or "hybrid" theories of punishment, not all of which claim to derive from Kantian thought. As a historical matter, one might see mixed theories as an obvious solution to a philosophical problem: that utilitarianism and retributivism are both attractive but ultimately deficient theories with which to justify punishment. As Whitley

19 KANT, supra note 2, at 28 (6:235-36).

20 Id. Related cases Kant mentions are the woman who kills her illegitimate child and the military officer who kills another in a duel-though each kills, neither is punishable. Id. at 108-09 (6:336). These cases are even stranger given contemporary mores: children born out of wedlock are not subject to lifelong "disgrace," and we do not think of one who "fails to respond to a humiliating affront with a force of his own" as being a coward. Id. Still, setting aside such feelings we might have about the examples, the main point here is that Kant approves of non-punishment of murderers in certain cases, which is puzzling if he is a pure retributivist.

21 For additional considerations, see Scheid, supra note 1; Byrd, supra note 4; Ekow Yankah, Crime, Freedom, and Civic Bonds: Arthur Ripstein's Force and Freedom: Kant's Legal and Political Philosophy, 6 CRim. L. \& PHIL. 255 (2012). 
Kaufman puts it: "[i]n the mid-twentieth century, it was widely believed that the problem [of justifying punishment] had finally been solved. In a burst of creativity, a number of different thinkers - most famously H.L.A. Hart and John Rawlsdeveloped an approach that purported to reconcile utilitarianism and retribution . . .. ."22 Although Kaufman believes the mass experiment with mixed theories to have been ultimately unsuccessful from a philosophical standpoint, the tradition seems to be alive and well with respect to interpretation of Kant.

To give a salient example of someone who applies the "mixed" viewpoint to Kant, B. Sharon Byrd argues, based on textual as well as "[h]istorical considerations" 23 that "for Kant general deterrence was the justification for criminal law provisions threatening punishment. Retribution, on the other hand, was not a goal or reason for punishment but rather a limitation on the state's right to inflict punishment ...."24 Thus one may threaten to punish citizens, with the goal of deterring crime, but "[a]fter a criminal violation has occurred, ${ }^{25}$ the focus shifts from instrumental priorities of general crime prevention to the just treatment of the individual." 26 The "just treatment of the individual" is embodied in a "limitation on the state's right to inflict punishment," which limitation is the principle of lex talionis, or retributive proportionality in punishment. Byrd notes that some prominent scholars, such as H.L.A. Hart, have interpreted the "state's right to inflict punishment" as deriving from lex talionis itself. ${ }^{27}$ Kant, though, does not make this argument-lex talionis is clearly important to his view of punishment, but it is not cited as a justification for that practice. ${ }^{28}$

22 Whitley Kaufman, The Rise and Fall of the Mixed Theory of Punishment, 22 InT'L J. OF Applied Phil, 38, (2008).

23 Byrd, supra note 4, at 151. Byrd does not develop her "historical" argument; she cites one journal article for the proposition that "[t]he distinction between punishment as a threat used actively to bind an individual to the rules of conduct and the execution of punishment as a response to the breach of one's obligation was made both before and immediately following Kant's critical philosophy." Id. at 184. I do not, however, think that this point is crucial for her argument, which is mainly conceptual and textual.

24 Id. at $152-53$.

25 This is the phrase that Byrd uses, but it seems likely that she means after a conviction has been obtained. The commission of a crime paradigmatically initiates a process of investigation, accusation, and trial, all of which is public and apparently entails the promotion of various values, among them truth, preservation of the defendant's rights - but also deterrence. Surely, then, she must mean that the shift from deterrence to retribution occurs after someone has been convicted of a crime.

26 Byrd, supra note 4, at 153.

27 Id. at 152.

28 Byrd conceives of the justification in a libertarian fashion: "for Kant law is a means of coercive force applied to guarantee a necessary minimum of external conditions. . .. The conditions for this universal freedom are secured through civil society. . . The purpose of the criminal law is to protect this social order." Id. at 153-54. Scheid seems to agree that the libertarian interpretation is correct: "an individual enjoys freedom to the extent that there are activities he may undertake without forceful interference from other people. Essentially, freedom is the absence of coercion by others." Scheid, supra note 1 , at 269. Punishment is merely a hindering of a hindrance; "[a]ny infringement of the individual freedom defined according to universal laws is wrong, and so coercion which prevents the infringement of such individual freedom is justified." Id. The strict libertarian reading is, I think, problematic - I shall not explore that argument further here, except to reiterate that it seems inconsistent with his conceptions of justice and 
Byrd correctly points out that Kant does not claim that lex talionis does the work that pure retributivists need it to. It is, at most, a limiting principle on the extent of punishment. Scheid phrases the limiting potential of lex talionis this way: "What right does the state have to punish an individual for the purpose of deterring others? Indeed, whether the individual is guilty or not, how can the state ever be justified in using a person in this way, as a mere means?"29 Even if we agree that "the general justifying aim of punishment is crime control, this goal must nevertheless be pursued in a morally acceptable way, that is, in a way which gives full moral respect to the persons to whom the penal system is applied." ${ }^{30}$ Lex talionis thus acts as a check on the tendency of the state to over-punish individuals who breach the terms of the social contract.

So on this "mixed" interpretation, the role of lex talionis is as a guarantor of "moral acceptability" of the punishment itself. Crime-control considerations (deterrence) give us reason to threaten citizens with punishment. But the "law of retribution" guarantees that, if someone does in fact break the law, she will be punished to the extent she deserves - and no more (but, of course, also no less). This would seem to allay one concern that is commonly raised about purely utilitarian punishment schemas: that they license the punishment of the innocent and the overpunishment of the guilty. Kant would, on this view, permit citizens to be threatened with punishment for violations of the UPR, to whatever extent necessary to deter crime-but would ensure that the actual punishments citizens receive were limited by lex talionis.

This view has some obvious advantages over the pure-retributivist one. It explains the apparent contradiction in Kant's use of deterrence language in some places and retribution language in others: he simply has in mind two different functions of criminal punishment (and perhaps neglects to distinguish clearly between them in his text). The hybrid approach also appeals to common-sense intuitions about the need for societies to deter crime - a theory of criminal justice that sees no role for deterrence would, at best, be one that departs radically from most countries' penal practices.

There is, however, a problem with the hybrid view, which suggests that Kant would not have endorsed it. Some reflection on how criminal justice systems function will show that bifurcating the criminal law into threat and execution is pragmatically bizarre and possibly incoherent. Assume for a moment that we had a mixed deterrence-retributivist system. Legislators under this system would need to enact legislation that threatens citizens optimally. So, for example, we might find that threatening fifteen years in prison for burglary is the best way to deter people from committing burglary. Of course, it is unrealistic to suppose that nobody will ever commit burglary even when the threatened sentence is this high. Suppose, then, that a judge is now faced with sentencing a burglar - one of the few who were not dissuaded by the severity of the law. We might find that lex talionis demands that the burglar receive five years in prison for his crime. True, we threatened him with fifteen years, but he deserves exactly five years.

citizenship that Kant would think the sole justification for criminal punishment is the minimalist protection of "social order." Scheid, supra note 1, at 272.

30 Id. 
We now face a conundrum. If the judge imposes five years, then he has rendered the legislation ineffectual. Citizens would observe that, despite what the law says, the burglar in fact only gets five years. The deterrent effect of the fifteenyear threat is vitiated - indeed, we might expect that the only deterrent effect would be of the actual five-year sentence. On the other hand, if the judge were to impose fifteen years, then the deterrent effect of the legislation would be upheld-but at the impermissible cost of violating lex talionis. So it would appear that the mixedjustification view leads either to illegitimacy (the law is deceptive and untrustworthy) or incoherence (lex talionis, putatively necessary, in fact cannot provide the judge with a reason for deviating from what the legislature has threatened).$^{31}$

A related question is whether it is reasonable that, as Byrd would have it, our focus should shift entirely away from "instrumental" concerns once an accused criminal has been convicted. Is it really the case that "just treatment of the individual" is the only thing that we ought to be concerned with in determining her punishment? This seems unlikely, for several reasons. Common sense would lead us to assume that, in order for the deterrent effect of a "threat" to be effective, we would at least need to publicize criminals' sentences - otherwise, the threat of criminal sanctions would be an entirely empty one. Moreover, Kant would surely not say that the only thing that matters once a criminal has been sentenced is how we treat him. This is an important concern-perhaps the most important onebut other considerations merit our attention: whether a dangerous offender will be incapacitated, whether there is a mechanism for publicizing the punishment to the public for deterrence purposes, whether anyone victimized by the crime has been vindicated, and so forth.

For example, suppose that David is convicted of raping Victoria. On the hybrid view, the deterrent purpose of (the threat of) punishment is served by the promulgation of public legislation proclaiming that rape shall be punished by exactly thirty years in prison. This lengthy sentence should, the legislature thinks, dissuade any rational person from committing rape. Once David has been convicted, though, all that matters is discerning the "just" sentence for him. But in order to have a hybrid system be coherent (or something besides a lie), then lex talionis has to play some role at the deterrent stage (the legislature has to figure out what is the appropriate penalty - or range of penalties, perhaps - for a given crime). Conversely, deterrence must play a role in sentencing (it would seem perverse from a deterrence standpoint if we sentenced David to a $\$ 100$ fine and 20 hours of community service in lieu of prison, even if that were demanded by lex

31 It would also be possible for lex talionis to demand a more severe punishment than necessary for deterrence purposes, though this seems less likely in practice. In fairness, my example presupposes that would-be criminals have access to, and in fact obtain, information about sentences handed down by the criminal courts. It might be possible to construct a criminal justice system where all sentences are private-this is the default position in juvenile delinquency cases in the United States, for example, though they are not technically "criminal" matters. It seems unlikely, however, that nobody would catch on to the fact that there was a radical difference between threatened and imposed punishments - surely questions would be raised when Uncle Bill suddenly turned up at the family reunion only five years after his burglary conviction. More importantly, a criminal justice system that was radically private in this way might face significant questions about procedural fairness. In any event, it seems very unlikely that this is the kind of system that Kant had in mind - and it is certainly not one likely to be relevant to readers. 
talionis). Surely, if we care about deterrence at all, then we still care about it when we are punishing David. So the "focus-shifting" aspect of the hybrid view is also problematic.

To be fair, interpreting Kant via a mixed theory that separates criminal punishment into threat and execution does seem to be an improvement over the pure-retributivist position. And perhaps there is some way to save the hybrid or mixed approach in order to avoid the kind of problem I have identified. I think, however, that we need not make such an attempt—-because there is a third way of interpreting Kant's views on punishment which will suggest that whatever roles deterrence and retribution play in Kant's theory, they are at most derivative features of his account of justice as presented in the Rechtslehre.

\section{A Third Way: Punishment as a Requirement of Civic Freedom}

Kant's account of criminal punishment is, I believe, best understood as one facet of his theory of justice. As explained above, Kant conceives of a just society is one whose basic structure is founded on the Universal Principle of Right. The UPR guarantees that all citizens will be able to pursue their chosen ends, to the extent that those ends are compatible with those of their fellow-citizens. We are free, in the political (rather than moral) sense, when we choose to be governed by just laws, which in turn ensure that our wills are not governed by others'. A requirement of justice, then, is that each of us, as citizens, willingly submits to the just laws of our community.

Willful violations of these just laws - specifically, of those laws which ensure the political conditions of citizens' civic freedom - are properly referred to as crimes. A criminal is someone who has willfully violated the civic freedom of his fellow citizens; he has not only interfered with others' freedom, but has also done so in a way that undermines the foundational structures upon which such freedom is based. ${ }^{32}$

A criminal, then, is someone who has broken the reciprocal bond that is the foundation of a just society. The "rightful condition" of civil society has been upset. According to Kant, though, restoring a state of free, equal, and independent citizenship depends crucially on the availability of state coercion-indeed, this is why he says that such coercion is necessary. ${ }^{33}$ A lack of state power (or willingness) to punish criminals would have obvious ramifications for all citizens' civic freedom. If my freedom to pursue my chosen ends is threatened in a significant way by a fellow-citizen's behavior, then I can reasonably expect the state to step in and prevent or rectify such "hindrance" to my freedom. ${ }^{34}$

32 Note that if one violates another's civic freedom, but lacks the will to do something incompatible with the UPR (i.e. does not act on such a maxim), then the violation is, by definition, not a criminal act. The state may be justified in using some kind of lesser coercion in order to restore the rightful condition that existed before, but is not justified in violating the actor's civic freedom.

33 Kant, supra note 2, at 89 (6:311-12). Note that Kant's view is retributive in this limited sense: crime necessitates punishment, and so punishment will always be in "retribution" (a more neutral term might be "response") for a crime.

$34 \quad I d$. at $25(6: 231)$. 
This line of reasoning has strong intuitive force. We perceive societies that lack adequate police and judicial powers-or willingness - to prosecute criminals as being less free than societies which have such capacities. We feel that our government does wrong, and we worry about our own rights and those of other citizens, when it fails to punish certain classes of offenders for spurious reasons - racial bias being an obvious example. The State is, then, rightly viewed as obligated to protect us against violations of the conditions of civic freedom, and to hold people who do commit such violations accountable for their actions.

The fact that the state is obligated to punish criminals in order to restore a rightful condition consistent with the UPR is helpful. Still, we may be left wondering how it is that punishment could be justifiable for one who embraces Kantian values, such as respectful treatment of all human beings. After all, "[c]riminal punishment is coercive state power in its most brutal form. ... If locking human beings in cages or killing them is not a bad way to treat people, it is hard to imagine what would be. Punishment, in short, seems to involve conduct that is in itself wrong." ${ }^{.35}$ And even when punishment is administered humanely, it still seems to violate citizens' civic freedom. A fine or a community service order are, after all, still coercive in nature and, therefore, restrict the citizen's ability to fully govern himself. What, then, gives the government the right to impose such punishments, let alone more severe ones (such as imprisonment)?

The answer is, in one sense, quite simple. A citizen's civic freedom is, as we have seen, dependent upon his respect of others' civic freedom. But a crime is, by definition, a willful violation of another's freedom. Therefore, it follows that someone who has committed a crime loses the protection of the UPR. A criminal has, in a sense, forfeited or lost his civic freedom. ${ }^{36}$ And, if he has no civic freedom, then it would not be unjust for the government to treat him coercively.

Now, this answer is perhaps too simple. For it would appear, upon closer inspection, to engender some questionable results. For one thing, if someone has lost his civic freedom entirely, then the government would appear to be justified in doing anything to him. Someone who is not free could, after all, be made a slave. Another worry is that if someone lacks civic freedom, then he is not a citizen (at least not in the full Kantian sense). But if he is not a citizen, then his fellow-citizens have no obligations toward him as far as justice is concerned. They may retain some moral obligations toward him-but they would still be justified in imposing punishment on him themselves, rather than letting the government do so.

These concerns are unwarranted, however, because Kant places some definite limitations on the coercive power of the state - and these limitations are not merely ad hoc, but are results of the structure of civic freedom. First, Kant asserts that while criminals lose the "dignity of citizenship," they do not lose their human dignity. ${ }^{37}$ The difference between these types of dignity can be clarified by noting

35 Murphy, supra note 1 , at 1.

36 This account is probably compatible with the rights-forfeiture view of punishment, at least on some accounts. See, e.g., Christopher Heath Wellman, The Rights Forfeiture Theory of Punishment, 122 Ethics 371 (2012). It does, however, provide a clearer explanation of why we are justified in asserting that criminals forfeit their rights.

37 Specifically, Kant asserts that "no human being in a state can be without any dignity, since he at least has the dignity of a citizen. The exception is someone who has lost it by his own crime, because of which, though he is kept alive, he is made a mere tool of 
that, in the Groundwork, Kant refers to human dignity as arising from our capacity for moral self-legislation. ${ }^{38}$ The concomitant notion in the Rechtslehre, the dignity of citizenship, therefore refers to the capacity that citizens have to be co-legislators of just public law. In particular, the notion of civic independence (one key aspect of civic freedom guaranteed by the UPR) is of a citizen who acts "as a member of the commonwealth," which entails that he is a part of the "legislative authority [that] can belong only to the united will of the people." 39

This, then, explains why Kant says that criminals lose their dignity of citizenship: by violating justly enacted laws, they betray themselves as legislators. They remove themselves from the body of those who act according to the "united will," always upholding the UPR. Note, however, that the criminal retains her dignity of humanity. Human dignity is without "price" 40 it is not alienable, as property and even civic rights are. And because all human beings have an absolute duty to respect others' humanity, no just punishment could ever be administered that would violate human dignity. The state is therefore justified in treating criminals in ways that would ordinarily violate their civic rights, but not their human rights. ${ }^{41}$

So the first limitation on punishment is that the criminal's humanity must not be violated. Precisely what this means is debatable, but it seems clear that some kinds of treatment will be out of the question: torture, rape, and other sadistic practices are obviously incompatible with people's humanity, and even if the criminal has perpetrated such acts on others, we can never be justified in doing so to him. One important question, particularly for American criminal justice, is whether capital punishment is compatible with the respect of human dignity. As we shall see, Kant thinks so-but we might reasonably debate whether this is the case.

Another clear limitation on punishment has to do with who is doing the punishing. If offenders lose their civic dignity, then why could other citizens not punish them? Kant thinks part of the social contract (wherein we, as members of a

another's choice (either of the state or of another citizen)." KANT, supra note 2, at 104 (6:329-30) (emphasis removed). One oddity here is the parenthetical at the end of the passage, which makes it sound as if Kant thinks that criminal punishment can somehow be meted out by private citizens, rather than only by the state. This contradicts his later statements about punishment being the province of the government alone. It is possible that Kant has in mind some kind of lesser (civil) wrong; this may be what he has in mind when he later speaks, without clarification, of "private crime." Id. at 105 (6:331). I shall proceed under the assumption that this passage is either an aberration, or explicable in another way.

38 See Immanuel Kant, Groundwork of the Metaphysics of Morals (Mary Gregor trans.), in Immanuel Kant: Practical Philosophy 37 (Paul Guyer \& Alan W. Wood eds., Cambridge Univ. Press, 1996) (4:434-35).

39 KANT, supra note 2, at 91 (6:313-14).

40 KANT, supra note 38, at $84(4: 434)$.

41 That Kant thinks there are certain rights which nobody can lose, even via criminal activity, is supported in other passages. In answer to the question of "what kinds of punishment are [justifiably] adopted" by the government, he answers that "the legislator must also take into account respect for the humanity in the person of the wrongdoer." KANT, supra note 2, at 130 (6:362-63). This leads him to suggest, as noted previously, that some crimes may require a substitute punishment when imposing lex talionis in a literal manner would violate the defendant's humanity - as in the case of rape. Id. (I am not convinced that Kant's solution - castration - qualifies as much more humane, but the principle seems sound even if the application is questionable.). 
just community, agree to act in accordance with the UPR) entails leaving the right of punishment in the hands of the government. Thus, for example, he states that the "right to punish is the right a ruler has against a subject to inflict pain upon him because of his having committed a crime." ${ }^{2}$ He reiterates this in a discussion in the Tugendlehre on the difference between vengeance and punishment: "punishment is not an act that the injured party can undertake on his private authority but rather an act of a court ... [for] no one is authorized to inflict punishment and to avenge the wrongs sustained by them ...."43 Kant is not as clear as he could be about why this is the case - he seems to take it for granted whenever he mentions punishment — but it is presumably because of concerns similar to those Locke raised, nearly a century earlier, about the difficulties of leaving punishment in the hands of individuals. In the state of nature, we can never be sure whether we are punishing the criminal too much or too little, or letting our personal biases interfere with a rightful determination of deserved punishment. It is therefore necessary to give up our power to punish to an impartial judge in order to ensure that criminals are punished to the proper extent. ${ }^{44}$

In addition, recall that punishment restores the "rightful condition" of civil society. But individuals cannot, on their own, create such a condition, which is the product of the "united will" of a body of citizens. It follows that individuals cannot, by themselves, restore such a condition once it has been disrupted by a criminal act. Only the state - which, of course, is but a representation of the "united will" - can punish criminals in such a way that the reciprocal nature of the UPR can be upheld.

We have, then, good Kantian reasons to assert that punishment must be administered only by the state. We also saw that punishment which violates human dignity cannot be justified. One problem remains, however. Even if we were certain that a particular type of punishment—say, confinement within a safe, well-maintained correctional facility-was permissible, there would seem to be nothing to prevent the government from using it in ways that seem, intuitively, to be unjustifiable. For example, the government could imprison a petty thief for the rest of her life. Even if imprisonment as such is not inhumane, there is something intuitively unjust about imprisoning someone for many years for a minor offense. This is, of course, the oft-discussed problem of proportionality. How are we to ensure that whatever punishment we impose "fits" the crime?

As mentioned in subsection A above, Kant holds that the nature and extent of a punishment should be determined by the principle of lex talionis: punishments should be, as far as possible, identical to the crime committed. Kant thinks that this will answer both the means and extent questions - thus when someone steals, his property is forfeited; when he commits murder, "he must die." 45 This,

Id. at 104 (6:331) (emphasis added).

Id. at 207-08 (6:460).

4 See the second chapter of John Locke, Second Treatise in Two Treatises of Government (Mark Goldie ed., Tuttle Publishing, 2000). Kant's brief discussion of the problems human beings would face in the state of nature seems to echo Locke's concerns - thus such a condition would be "a state devoid of justice in which when rights are in dispute, there would be no judge competent to render a verdict having force." KANT, supra note 2, at 90 (6:312) (emphasis removed and parenthetical Latin translations omitted).

45 KANT, supra note 2, at 106 (6:333) (emphasis removed). 
though, is troubling. Lex talionis is, after all, one of the reasons scholars have traditionally thought of Kant as a retributivist. Moreover, a strict insistence on this principle - even excepting cases where its application would result in violations of human rights - can seem unfair in many cases. For example, we often assume that someone who is a first-time criminal offender ought to receive a lesser sentence than someone who has spent a lifetime violating the law. But applying lex talionis would seem contrary to the intuition that we should mitigate (or aggravate) sentences based, not merely on the nature of the offense, but also on the circumstances of the offender.

Perhaps some insight can be gained by considering why Kant seems to insist on lex talionis. What argument could justify his reliance on this principle as the only proper response to questions about extent and method of punishment? Here is the main passage in the Rechtslehre on this topic:

But what kind and what amount of punishment is it that public justice makes its principle and measure? None other than the principle of equality (in the position of the needle on the scale of justice), to incline no more to one side than to the other. Accordingly, whatever undeserved evil you inflict upon another within the people, that you inflict upon yourself. . . [O]nly the law of retribution (ius talionis) - it being understood, of course, that this is applied by a court (not by your private judgment) - can specify definitely the quality and the quantity of punishment; all other principles are fluctuating and unsuited for a sentence of pure and strict justice because extraneous considerations are mixed into them. ${ }^{46}$

Of note here is that the principle motivating lex talionis is not retribution-it is equality. Although Kant uses the word "retribution," it is employed only to identify lex talionis, not to justify it. Kant's sole reason for claiming that lex talionis is the only just way to punish is that any other way of meting out punishment would be "fluctuating." Competing principles would cause the scales of justice to tip to one side or the other - to become unbalanced - resulting in an inequitable distribution of punishments.

46 Id. at 105-06 (6:332) (emphasis in original). Note that Kant's reference to "within the people" is consonant with the view that Kant conceives of crime as a breach of the social contract based on the reciprocal nature of the UPR. Wronging someone outside the state is not a crime (though morally wrong), because one is not legally bound in a reciprocal relationship with that person. The State cannot overstep its authority and punish wrongs that occur to people who are not parties to the social contract. This raises the question of whether Kant's theoretical framework can provide a reasonable account of international criminal law. I cannot hope to broach that topic here, though it should be noted that Kant does discuss matters of international justice, particularly in Toward Perpetual Peace: A Philosophical Project (Mary Gregor trans.) in Immanuel Kant: Practical Philosophy 315-351 (Paul Guyer and Alan W. Wood eds., 1996) 
In section II, I will argue that lex talionis ${ }^{47}$ should be supplemented by a more flexible principle of punishment based on an aspect of civic virtue. For the moment, though, it is sufficient to note that, whatever misgivings we might reasonably entertain about lex talionis, Kant thinks that this principle serves the end of civic equality, and surely he is right that utilitarian calculations should not alter our commitment to just punishment. We should not be prepared to sacrifice the innocent at the whim of the majority, nor should not be willing to release the guilty because it is politically expedient. We might wonder whether consideration of the criminal herself, or even the crime victim, ought to cause us to alter our initial calculation of the degree of punishment the criminal deserves - but this is, I think, not the kind of factor that Kant is most worried about here. He seems, rather, to be cautioning against the kind of "Pharisaical" reasoning that would cause us to, as it were, crucify those who were above reproach on the one hand, and fail to mete out just punishment to deserving offenders on the other, simply because doing so would be unpopular. ${ }^{48}$

Similar considerations seem to be at work in another passage, where Kant argues that it would be impermissible to offer to "preserve the life of a criminal sentenced to death if he agrees to let dangerous experiments be made upon him and is lucky enough to survive them, so that in this way physicians learn something new of benefit to the commonwealth." ${ }^{49}$ Kant thinks that this would be unacceptable because "justice ceases to be justice if it can be bought for any price whatsoever." On the one hand, one might wonder why this would be so offensive. If someone already condemned to death offered to undergo an experiment in the hopes of helping other people, why should we not allow him to do so? Would this not be a noble gesture? Might it not be born of a desire for penance on the part of the offender?

Kant's objection, however, is probably twofold. First, this kind of experimentation seems to use the criminal's very life as a mere means to an end, which is categorically prohibited by the moral law. ${ }^{51}$ Second, the proposal permits the criminal to buy his way out of punishment. If one can offer one's body to science in order to escape punishment, why could one not offer the government enough money to reduce one's sentence? This might seem more repugnant than

47 For a more detailed argument against lex talionis, see Sarah Holtman, Toward Social Reform: Kant's Penal Theory Reinterpreted, 9 UtiLitas 3 (1997). Holtman argues that Kant made some unwarranted empirical assumptions that motivate his discussion of lex talionis; if we do not accept these assumptions, then lex talionis becomes a less compelling principle. Id. at 18. Assessing the strength of each of these assumptions would be complicated; Holtman's main project, though, is not to argue definitively against Kant's insistence on lex talionis, but simply to point out that this commitment does not follow necessarily from his larger theory of justice. Id. My goal in the latter half of this paper is similar.

48 KANT, supra note 2, at 105 (6:331). Kant's allusion is presumably to the New Testament story of the Roman leader Pilate placating the Pharisees (portrayed as hypocritical religious leaders concerned with maintaining their positions of authority) by ordering Jesus (though innocent) to be killed, and a robber (though guilty) to be set free. See Matthew 27, esp. 20:24.

49 KANT, supra note 2, at 105 (6:332).

50 Id.

51 Kant, supra note 38, at 80 (4:429). 
the possibility of medical experimentation - but Kant avers that, if justice is to be equal among citizens, then one cannot use any means whatever, be it one's money or one's body, as a get-out-of-jail card. To allow otherwise would be to offer an advantage to some criminals that is not extended to others-and this inequality would be impermissible from the standpoint of justice. ${ }^{52}$

The bottom line here is that Kant thinks lex talionis is the proper answer to questions about the mode and extent of punishment because it is conducive to treating criminals equally, and equality is important in a system of Kantian justice. Whatever qualms we might have about Kant's embrace of lex talionis, however, we have seen how punishment can reasonably be viewed as a requirement of Kant's account of civic freedom. And this account is, I hope to have shown, significantly more convincing than the existing retributivist and hybrid ones.

\section{OBJECTIONS to THE PRECEDING INTERPRETATION}

Thus far, our interpretation of Kantian punishment as a facet of his theory of justice sounds reasonable. Can we, though, reconcile this interpretation with textual concerns the hybrid theorist raises? Consider first the references Kant makes to deterrence (and occasionally rehabilitation) as apparent goals of punishment. Threatening citizens with punishment for the violation of the UPR can be seen as a way of preserving the freedom, equality, and independence of all concerned. Such deterrent threats, if effective, reduce the likelihood that a citizen will be victimized by a criminal. Deterrent threats of punishment are applied equally to all citizensnobody is singled out as a potential criminal — which sends the message that the state takes seriously the rights of all citizens and wishes all to benefit from the freedoms gained by participation in civil society. They also put potential offenders on notice that their freedom will be diminished, and their status as independent citizen-agents jeopardized, should they choose to act in abrogation of their basic duties as citizens to uphold the UPR.

Thus, while deterrence is arguably an important aspect of (the threat of) criminal punishment in a Kantian scheme, this would only be the case insofar as deterring crime actually promoted Kantian justice within civil society - an important point that hybrid theories do not recognize. This is why we are able to evaluate the justness of criminal laws independently of their deterrent efficacy; unjust laws may well serve deterrent purposes admirably but nevertheless be problematic because, say, the act being punished is one compatible with (or even necessary for) civic freedom.

52 What if the medical experimentation were offered equally to all prisoners, or all prisoners condemned to death? Would this not fulfill the equality requirement? If so, perhaps this is not all that Kant is concerned about. I doubt, however, that this scenario would really be indicative of equality, at least of the kind Kant cares about. If all prisoners took part in the medical experiment voluntarily, it would still be the case that some would live and some would die. Or, even if the drug worked perfectly as expected, the scenario would still entail the risk of some living and some dying. Human life may well be characterized by random luck, but Kant seems to be saying that it is not a proper basis for a just social institution. We ought to demand more of political equality than having an equal chance at entering the lottery. 
Rehabilitation as a (partial) aim of punishment from a Kantian perspective is a more interesting question. Insofar as the criminal justice system could "rehabilitate" offenders, it is worth asking what this might mean. Perhaps we could conceive of a kind of civic rehabilitation, in which the offender is offered help regaining his literal and figurative citizenship: his place in the community, and his commitment to the civic freedom of his fellow-citizens. This type of rehabilitation seems reasonable, and compatible with Kant's view of civic freedom.

The justice-based interpretation can also make sense of the seemingly strange passage on "necessity" mentioned in above: the drowning man who, "in order to save his own life, shoves another, whose life is equally in danger, off a plank on which he had saved himself." ${ }^{53}$ Kant does seem to say that the reason the drowning murderer is unpunishable is that punishment would have no deterrent effect in such a case. But a closer look reveals that Kant's main point is that "there could be no necessity that would make what is wrong conform with law." 54 On the one hand, Kant seems to be saying that a morally bad act can never be "legal": we would not want our law to say that murder is ever permissible. On the other hand, there is a certain category of bad-luck cases where murder does not, strictly speaking, violate the UPR, and where it would therefore be inappropriate to apply coercive punishment.

If I am drowning in the ocean, I am not acting as a citizen within civil society, but as an animal struggling for survival. The circumstances are not such that the demands of justice are relevant-nor can they be met. No action that I take under such circumstances will preserve the aims of the UPR. If I let myself die (which Kant acknowledges may be the more noble and morally worthy act), I fail to preserve my own freedom; whereas appropriating the plank for myself will fail to preserve the freedom of the other drowning man. There can be no equality here, since one of us must die. And our status as independent citizens is hardly at issue at the moment. Since state coercion is justifiable only to preserve the aims of freedom, equality, and independence of citizens, it fails to be relevant in this particular case - even though we privately might judge that I lack some personal virtue because I chose to save my own life at the expense of another's. In legal terms, I am excused, though not justified: what I did might not be morally right, but I should not be punished for having done it.

Thus, while the hybrid theorist can point to the few references to deterrence in order to explain the "necessity" case, the justice-based interpretation provides a fuller and more compelling explanation of that initially abstruse passage. Now, however, we need to confront a particularly well-known section of the Metaphysics of Morals that is commonly used to paint Kant as a hard-nosed retributivist. Can we square Kant's discussion of capital punishment with the justice-based interpretation?

Kant categorically rejects any sort of mitigation or tempering of capital punishment for convicted murderers. ${ }^{55}$ If the death penalty is taken to be merely

\footnotetext{
KANT, supra note 2, at $28(6: 235)$.

$I d$. at $28(6: 236)$.

Kant does say that we ought to execute murders humanely. Id. at 106 (6:333). However, this seems a rather minor concession considering that he apparently does not consider the possibility that any murder might be justly punished by anything other than death (except of course in the "necessity" cases).
} 
the starkest example of Kant's retributivist stance-that is, if Kant intends us to be able to replace "murder" with any other crime and "death" with a concomitant penalty - then there would seem to be little need to appeal to other principles, as both the hybrid and justice-based interpretations attempt to do.

I believe, however, that this is not an accurate reading of the death-penalty discussion, which begins precisely by distinguishing murder from other crimes. Kant prefaces the murder passage with a discussion of theft, pointing out that, since taking all a thief's possessions would result in a burden on the state to "provide for him free of charge," the thief can be forced to perform "prison labor" instead. ${ }^{56}$ Kant believes murder to be different in kind, however, from ordinary crimes such as theft. Murder ends a human existence not only in the biological sense but also in the Kantian one, where human life is particularly valuable because of its potentiality: to be human is to be free and autonomous, capable of willing and creating and reasoning. To kill is to deprive a human being of such potential. For all other offenses, ${ }^{57}$ no matter how heinous, the victim at least remains capable of realizing that potential (albeit possibly to a lesser degree than before the victimization). In the context of life in civil society, murder permanently deprives the victim of the freedom, equality, and independence of citizenship. Again, no other crime can effect such a result.

For this reason, Kant thinks that, while the thief can be punished by a method other than stealing, if a criminal "has committed murder he must die. Here there is no substitute that will satisfy justice. There is no similarity between life, however wretched it may be, and death, hence no likeness between the crime and the retribution unless death is judicially carried out upon the wrongdoer." ${ }^{\circ 8}$ Whether or not we agree with Kant about this, the important point here is that Kant's commitment to capital punishment is grounded at least partly in a contemplation of the magnitude of the injustice perpetrated upon a victim by a murderer. Many will disagree with Kant's dramatic assertion that "blood guilt" will "cling to the people" who do not "insist upon [capital punishment]; for otherwise the people can be regarded as collaborators in this public violation of justice." ${ }^{95}$ Still, Kant is surely correct to emphasize the importance of punishment for certain types of crime, most notably murder. Failure to prosecute and punish murder amounts to a failure of justice: free, equal, and independent citizens can reasonably expect that the government will pursue and prosecute such offenses - and will naturally view

\footnotetext{
Id. at $106(6: 333)$.

57 Well, almost all. It is unclear whether Kant considers something like negligent homicide to be equivalent to murder. In that situation the negative impact of the defendant's actions is generally grossly disproportional to the defendant's punishment, which is normally something significantly less than life in prison, let alone the death penalty. I am setting aside for present purposes cases of crimes involving death where the defendant's mens rea is something less than intentional or knowing. Also, one could conceive of a situation where, say, the defendant only assaults the victim, clearly without the intent to kill, and the victim is rendered comatose for the rest of his life. In such a situation perhaps the defendant has committed an offense with substantively the same effects as a murder, although technically the victim has not died. Kant might simply treat this as a murder. I am also disregarding such difficult scenarios for now, since the distinction between murder and lesser crimes is usually much more obvious.

$58 \quad I d$. at 106 (6:333) (emphasis in original).
}

$59 \quad$ Id. 
police, lawyers, judges, and others as complicit in injustice if they fail to do so. If we were to accept the premise that the death penalty is the appropriate punishment for murder, then surely a failure to impose it would indicate a failure on the part of society to take murder seriously.

Many will nonetheless find Kant's argument in favor of capital punishment insufficient. We might think that, while murder is heinous and should be treated accordingly, the government ought to consider other options in punishing even the worst kind of criminals. If we are skeptical about the exacting demands of lex talionis in the first place, then we certainly should question whether homicide is really the only appropriate response to homicide. And while Kant criticizes an anti-death-penalty advocate for being "moved by overly compassionate feelings," perhaps justice would best be served by "tempering" retribution with mercy ${ }^{61}$ Moreover, even if we were to accept that for the "average" murderer death would be the appropriate penalty, it is easy to construct a scenario where it seems grossly unfair to impose this sentence. Even in the United States, where capital punishment remains legal in many states and on the federal level, the Supreme Court has restricted the practice where certain categories of individuals are concernednotably juveniles and those with mental handicaps. This seems right: surely at least some capital cases call for a "substitute" form of punishment.

Kant may simply not have thought out the injustice of executing certain classes of citizens. But we should also remember that Kant's initial attraction to lex talionis arises primarily out of a concern with equality. A common criticism of the death penalty as implemented in the United States is that it is racially biased. Although this is generally taken to be an argument in favor of abolishing capital punishment, one could understand why Kant, given a particular historical context, might insist on executing murderers. While it would be patently unfair to execute only black murderers while sparing the lives of white murderers, there is at least a sense in which equality would be served by executing all murderers, regardless of race. Many contemporary readers (including me) will find this conclusion incomplete, if not perverse - after all, we do not generally find it a good argument for clearly immoral practices (slavery, genocide, and so on) that people are victimized equally. If putting people to death is prima facie wrong, then the fact that we do it equally will not justify it morally. But, as Thomas Hill puts it, "considerations of comparative justice make understandable, even if not defensible, Kant's thought that the longstanding (supposedly) just policy of executing murderers should not be abandoned" until everyone has received the same kind of treatment. ${ }^{62}$

Thus, regardless of one's feelings about capital punishment, Kant's endorsement of the practice can be explained within the context of a prior commitment to the promotion of a just social order - one in which citizens' civic freedom is of primary importance. We might easily disagree with Kant's conclusions while retaining the general structure of his theory of punishment.

\footnotetext{
$60 \quad$ Id. at 108 (6:334-35).

61 See Carol S. Steiker, Tempering or Tampering?, in Forgiveness, MerCy, AND ClemenCy 16 (Austin Sarat \& Nasser Hussain eds., 2007).

62 Hill, supra note 18 , at 434.
} 


\section{E. CONCLUSION}

The foregoing constitutes an overview of three competing interpretations of Kantian punishment. I have argued that an interpretation based on Kant's account of justice - wherein the purpose of punishment is to preserve the civic freedom of all citizens - is superior to the standard retributivist and hybrid accounts. Further work remains to be done in order to show what practical implications this interpretation has for a criminal justice system aspiring to fulfill a Kantian model of justice. First, however, we must address a salient issue I mentioned and left unresolved: whether we should accept lex talionis as the ideal way of determining the nature and extent of criminal punishment.

\section{Punishment and Civic Virtue}

If we agree with Kant that criminal punishment is morally justified, even required, then how do we determine the appropriate punishment for a given defendant? As I discussed in section I of this paper, Kant's response is simple: punish according to lex talionis. I suggested, however, that even if we agree with Kant's argument for the justification of criminal punishment, we ought to be skeptical of his reliance solely on this principle. In this section, then, I will argue that the second component of Kant's theory of justice - his account of civic virtue - can provide us with rationale for deviating from lex talionis. In order to do so, I use the novel approach of deploying Kant's moral theory in order to understand and strengthen his political theory. In particular, I will focus here on one moral value which, I will argue, is a desideratum of any just system of criminal punishment: moral cognition. In order to see what moral cognition has to do with criminal punishment, I shall first need to explain what role this concept plays in Kant's moral theory.

\section{A. The Duties of Conscience and Moral Cognition}

In the Tugendlehre, the part of the Metaphysics of Morals concerned with personal morality, Kant describes two duties that one owes to oneself as an autonomous moral agent: the duty to be one's "own innate judge," ${ }^{63}$ and the duty to "know [one]self." ${ }^{64}$ The former is tied to Kant's conception of conscience, which he analogizes to a court of law. In Kant's simplified courtroom, there is an accuser (the prosecutor), an advocate (the defense attorney), and a decision-maker (the judge). The attorneys plead their case, and the judge renders a verdict ("condemnation or acquittal"). ${ }^{65}$ Conscience, for Kant, is an analogous procedural mechanism internal to the rational moral agent. One brings charges against oneself based on some putative lapse of morality (as a prosecutor), defends one's actions against such charges (as a defense attorney), and passes judgment on oneself (as a judge).

KANT, supra note 2, at 188 (6:437).

64 Id. at 191 (6:441). Kant appears to use the terms "self-knowledge" and "moral cognition" interchangeably. I shall do so as well when discussing Kant's moral theory. However, when I argue for an extension of this duty to the societal realm, I will use the term "moral cognition" exclusively.

${ }_{65}$ Id. at $189(6: 438)$. 
Finally, to this judgment is affixed a punishment: "happiness or misery" depending on whether the action has been judged to be morally worthy or not. ${ }^{66}$ Kant clarifies, though, that an "acquittal" cannot lead to a "reward" nor to "joy" but to mere "relief from preceding anxiety." 67 Furthermore, this internal tripartite courtroom drama is not only a capacity humans have, but is omnipresent in our consciousness: "Every human being has a conscience and finds himself observed, threatened, and, in general, kept in awe (respect coupled with fear) by an internal judge; and this authority ... follows him like his shadow when he plans to escape." ${ }^{68}$ Kant thinks that we cannot escape self-judgment — at least, perhaps, without significant efforts at self-deception.

One might question whether this conception of conscience-as-courtroom is satisfying. For one thing, why is it that there is no "reward" for morally right actions? We have a tendency to praise others for morally laudable actions that is perhaps as strong as our penchant for condemning wrongdoing. We think good parents praise their children for right behavior as well as punish them for wrong behavior. It may be that children learn to act at least in part based on rewards and punishments, and Kant would say that they have for that reason not attained full moral development. We do, though, also reward adults who (for example) perform acts of charity in the community, or who sacrifice time and money on projects that benefit others. Perhaps these are supererogatory acts: public rewards are often bestowed upon those who seem to go above and beyond the requirements of morality. But what about the person who is overall an unsavory character but manages to rise above his animalistic inclinations to perform an act of "merely moral" quality? I am thinking, for example, of the addict who celebrates a few months free of her addiction, or the lifelong Scroogeish miser who finds joy in deciding, for once, to bestow his largesse on others. While Kant would find these people to have behaved in a morally worthy fashion, he seems to deny that they should be able to "reward" themselves for such laudable behavior. ${ }^{69}$

A second potential objection is that it seems at first glance far too simplistic in at least some cases to be able to make a binary judgment about the moral worth of one's actions. If your inner prosecutor calls you to task for having stolen something, it seems obvious that your inner judge will condemn you. Likewise, if you try to prosecute yourself for a momentary lapse of forethought (you unwittingly neglect to

\footnotetext{
Id. at 189 (6:439) (author's footnote).

Id. at $190(6: 440)$.

Id. at $189(6: 438)$.
}

69 One possible response, compatible with the one I will explore shortly, is that "rewards" of this latter type are not for acting morally in the fullest sense, but because someone like the addict is, in part, morally childlike. Rewards in this type of case function as encouragement toward fuller moral development, which includes the capacity to act free of the influence of addictive substances. Importantly, though, Kant would likely point out that all of us are morally deficient in some respect - we are all subject to influences that interfere with our moral autonomy. Incentives toward goodness (publicly bestowed or granted by oneself) are perhaps a permissible way to encourage moral development, so long as we do not make the mistake of thinking of the reward as the right reason for acting morally. For further discussion of Kant's views on moral training or education, see Barbara Herman, Training to Autonomy: Kant and the Question of Moral Education, in Philosophers on Education: New Historical Perspectives 255 (Amélie Oksenberg Rorty ed., 1998). 
hold a door open for someone), it seems equally clear that a well-functioning inner judge will acquit you. In many cases where there is an ostensible moral violation, though, it is not at all clear that the correct judgment is simply condemnation or acquittal. It seems that in many cases something more is required: "No, I didn't steal anything, but I had morally unworthy thoughts about doing so"; or "Yes, I failed to treat others with polite respect but I had a lot on my mind and had every intention to behave otherwise." How can the binary "courtroom" model account for the seeming necessity of making these more nuanced judgments?

One way of responding to these concerns is by appealing to the second duty that Kant presents in this section of the Tugendlehre: that of self-knowledge. ${ }^{70}$ Kant explains that to gain this knowledge one must "scrutinize" or "fathom" oneself, and that the knowledge sought is that of the "heart - whether it is good or evil." "71 The idea seems to be that we have a duty to explore our own motivations and desires, and to determine whether and to what extent our actions result from right reasons (conformity with the moral law) rather than morally suspect ones (desire for public approbation, say, or even the wish to be free from guilt). Kant thinks that engaging in this sort of "moral cognition will, first, dispel fanatical contempt for oneself . . . [and] will also counteract that egotistical self-esteem which takes mere wishes ... for proof of a good heart." 72

In other words, the particular self-judgments rendered by our conscience ought to be balanced by a more generalized view of our moral selves, which requires "impartiality" and "sincerity" about our "moral worth or lack of [moral] worth." I might, then, rightfully condemn myself for a moral failing, but nevertheless recognize when viewing myself objectively that I act in morally sound ways most of the time, and should regard myself as morally worthy, on the whole. On the other hand, I might correctly acquit myself of a certain transgression yet recognize that, all things considered, I was really just lucky that I did nothing wrong this time around.

The tempering effect of this type of self-knowledge-which allows us to avoid being both too hard and too easy on ourselves - supplies the apparently missing elements from Kant's description of the conscience. For although our inner judge might not allow us to experience "joy" simply because we are acquitted of putative wrongdoing, perhaps Kant would allow us to feel this sort of "reward" when considering ourselves objectively. Thus the aforementioned addict who has found the strength of will to remain free from her vice for a period of time might genuinely experience joy at having come this far since, all things considered, that is rather an impressive accomplishment for her. Similarly, although one's conscience renders a simple "guilty" or "not guilty" when considering the moral worth of a specific act, self-knowledge may be what supplies the "but" that we often attach to actions with moral content. Thus I might as an act of conscience correctly acquit myself of, say, a particular instance of lying, yet also as an act of moral cognition recognize that honesty is unfortunately not representative of my actions as a general matter and, therefore, I deserve very little self-satisfaction for not having lied on this particular occasion.

\footnotetext{
KANT, supra note 2, at 191 (6:441).

Id.

$I d$.

$I d$.
} 
One question we might pose is whether Kant intends for the self-knowledge aspect of our moral duty to diminish or augment in any way the penalty our conscience-qua-judge imposes on us for violation of the moral law. Kant does not address this explicitly. Indeed, he does not say much at all about what the penalty is for a guilty verdict rendered by one's conscience — only that it will be "happiness or misery." Presumably, though, not all moral failings ought to make us feel equally guilty: murdering and overindulgence in food hardly seem to warrant the same degree of self-imposed misery. It would seem, then, that there must be some means by which we determine how much misery or happiness we ought to allot ourselves based on our moral status. Since Kant does not supply such a mechanism in the section on conscience, but follows this up with the section on self-knowledge, it would be reasonable at least to consider whether this latter component of the moral being can do this work.

One might think that determining how much guilt to punish oneself with does not require self-knowledge in most cases. Obviously one who commits murder ought to feel much worse about himself than even the most reprehensible glutton. But the issue is not simply one of comparing two types of moral failings, but one type under different circumstances. Thus, for example, a person who has told a small lie one time to avoid a stressful confrontation might reasonably impose less misery on herself than ought to be entailed by the average lie; conversely, one who engages in systemic deception of a spouse in order to cover up an affair ought with full self-knowledge to impose a greater degree of conscience-ordered misery than for an average lie. ${ }^{74}$ Viewed this way, the duty of self-knowledge is intended not primarily to augment or diminish self-punishment but, more importantly, to discover the appropriate punishment for one's wrongs.

So far, I have argued that Kant intends the duty of self-knowledge or moral cognition to temper or refine the judgment we pass on ourselves through our conscience, based on the totality of our moral life circumstances. This is not the usual interpretation of Kant's view of conscience, which is commonly characterized as being "far from a gentle whisper of moral encouragement. It places us on trial for (perceived) moral failings, accuses us, passes sentence, and makes us suffer." 75 I am suggesting, though, that while Kant does view morality categorically in one

74 Kant is notoriously opposed to all forms of lying, even in cases where doing so would seem to be morally permissible, if not obligatory — as in the infamous "murderer at the door" scenario. See Immanuel Kant, On a Supposed Right to Lie from Philanthropy in Immanuel Kant: Practical Philosophy 605 (Paul Guyer \& Alan W. Wood eds., Mary Gregor trans., Cambridge Univ. Press, 1996). Part of the explanation for this may be Kant's concern about the moral wellbeing of the liar. Indeed, his discussion in the Tugendlehre on lying (supra note 2 at 183-83 (6:429-30)) falls under the general heading of "a human being's duty to himself merely as a moral being." Id. at 182 (6:428) (capitalization altered). By lying, even about small matters, one opens oneself to the possibility of self-deception. But proper moral judgment requires, above all, honesty with oneself, for moral cognition cannot function properly in the absence of such truth. It might be possible to agree with this general sentiment without taking the seemingly extreme position that Kant does with respect to lying to the murderer. But there is undoubtedly something right, even noble, about his unwavering commitment to the truth.

75 Hill, supra note 18, at 408. 
sense (one does or does not violate the self-legislated moral $\operatorname{law}^{76}$ ), he also views human beings as motivationally complex creatures, and invites us to acknowledge the complexities involved when we make choices that either comport with or deviate from the strict standards of morality. Such self-examination is just as much a duty to ourselves as is self-judgment, and inevitably leads to a more nuanced (and, often, more merciful ${ }^{17}$ ) view of our selves than Kant is usually given credit for.

My point in this section has been to show that, while Kant's conception of conscience can seem just as unyielding as his discussion of punishment is sometimes taken to be, this is at best a superficial reading. While self-judgment is an important to our moral life, so is the duty of self-knowledge or moral cognition. Only when we attend to both of these duties do we treat ourselves in a way that is respectful both of our moral agency, but also of our position as imperfect human beings subject to many influences other than the self-legislated moral law. Assuming this interpretation is correct, we might then ask whether a Kantian should countenance some analogue to self-knowledge or moral cognition in our relationships with others - a proposition for which I argue in the following section.

\section{B. Moral Cognition IN SOCIAL Life}

Kant does not discuss the capacity for moral cognition as applicable beyond the duty of self-knowledge. I think, however, that reflecting on the ways that we interact with other people will convince us that moral cognition is, in fact, a natural and essential part of social life - and that Kant would himself willingly endorse such an extension of this principle. Consider, for example, the types of judgments we must regularly make about the motives behind someone's actions. For example, imagine that a friend fails to follow through on a promise, or that a child misbehaves, or that a spouse deceives. What are we to do under such circumstances? ${ }^{78}$

I should think it clear that our response in such situations is highly dependent on the motives of the actor and background conditions of the action. If the friend is ill, or the child very young, or the spouse under intense stress, then we are likely to react in different-specifically, more merciful-ways than if the friend turns out to be selfish, the child old enough to know better, or the spouse systematically dishonest. But how do we make such determinations? Quite naturally, and without always being aware of it, we engage in moral cognition.

$76 \quad$ This is not to say that all Kantian duties are simple or immediately recognizable. Many of our "imperfect" moral duties may be difficult to discern; it may certainly be challenging to balance all the ends to which we are required to attend. It is only to say that Kant endorses a view by which we can, ultimately, give a specific answer to questions such as: "Is my action a morally praiseworthy one?".

77 I am thinking here of instances where we judge ourselves too harshly, as many of us are wont to do. Of course, at times we may also fail to appreciate the moral significance of our actions - we may underestimate the harm we have caused another, for example - in which case moral cognition will result in harsher judgment. My suggestion in section II of this paper will be that moral cognition in a social context will generally result in a tempering of our judgments rather than the reverse.

78 I have chosen negative actions because, as should be obvious, I will ultimately be drawing an analogy with criminal actions. Still, this is clearly the case with positive actions as well. We must determine how to respond appropriately to praise, gifts, and other indicia of social approbation, esteem, or love. 
For example, suppose that Joan's friend, Kevin, promises to watch her children one afternoon so that she can go to a job interview. Kevin does not show up, and fails to answer her phone calls. Joan, having relied on Kevin's promise, cannot find anyone else to watch her children on such short notice, and so she misses the job interview. This is a significant setback for her, since she has been unemployed for months, this job would have been ideal for her, and the interview cannot be rescheduled.

How should Joan react in this situation? That is, what should she do with respect to Kevin and their friendship? She has many options, such as telling Kevin what a great friend he is, pretending that nothing happened, writing an angry letter to him, refusing to ever talk to him again, explaining to him that she is upset, or hiring someone to kill him. Some of these options will be morally inappropriate due to their nature: killing someone without a sufficiently good reason is obviously immoral, and obsequiously praising someone who has harmed us may be as well. ${ }^{79}$ But many other options seem open to Joan. How is she to determine which ones are morally appropriate in the case at hand?

What Joan ought to do is, of course, try to learn more. Ideally, Joan will determine the facts of the situation with "impartiality" and "sincerity" in order to determine Kevin's "moral worth" with respect to this incident. ${ }^{80}$ Certainly, if Joan discovers that Kevin got into a serious car accident on the way to her home, then she ought to judge his failure to watch her children much differently than if it turns out that he spent all night drinking and therefore failed to wake up in time. It will matter, too, whether this is the first time Kevin has ever failed to follow through on a promise, or whether this is a chronic problem.

One might wonder whether expecting Joan to "morally cognize" Kevin in such a situation is unrealistic. Given the harm caused to her in this case, can we reasonably expect Joan to react in such a rational manner, when her initial inclinations will likely be anger at Kevin? Kant's moral theory is again helpful here. He proposes that personal virtue involves the "capacity and considered resolve to withstand a strong but unjust opponent." "[i]mpulses of nature" that beset human beings and create "obstacles" to doing their moral duty." $\$ 2$ It is perfectly natural for Joan to be angry-it is even, in a sense, justifiable. But surely Joan ought ideally to resist her impulse to react angrily. Perhaps this means she should never act out of anger ${ }^{83}$ - but it means at least that she should not act from anger until she knows all the facts about Kevin's failure to appear for babysitting duty.

\footnotetext{
See Kant's discussion of "servility," supra note 2, at 186-88 (6:434-37).

Id. at 191 (6:441).

$I d$. at 146 (6:380). See also the discussion of virtue, id. at 156-57 (6:394-95).

$I d$. at $146(6: 380)$.
}

Although it initially appears that anger is never a morally virtuous response to others' wrongdoing, I am unsure whether this is always the case. There may be something to be said for a kind of "righteous indignation" that impels us to seek justice for ourselves and others. Still, it seems clear that even this kind of response is improper until we are aware of all the relevant facts in a given situation. Helpful here is Kant's discussion of the "vices of hatred for human beings," in which he decries revenge, endorses forgivenessbut also distinguishes this from the "meek toleration of wrongs." Id. at 206-08 (6:458$61)$. 
In reality, of course, engaging in moral cognition will be particularly difficult when we have been seriously wronged by others. In some cases it may simply be psychologically impossible under the circumstances, and we must be wary of judging Joan if she fails to fulfill this moral duty in this case. Still, it seems reasonable to assert that the use of moral cognition in social circumstances such as Joan's is the proper moral ideal, however difficult it may be to attain in practice.

A more significant worry here, though, is that the purpose of moral cognitionproper judgment of others - is misguided. While we might be tempted to pass judgment on other people, and while we might in fact do this regularly, we really should not do so. One might appeal to religious aphorisms, such as "judge not, that ye be not judged" in support of this proposition. ${ }^{84}$ On this view, it would perhaps be acceptable to engage in moral cognition of oneself, but not of others; we should live in such a way that we accept others regardless of their actions, while leaving judgment in the hands of God. While there is certainly something noble about this kind of sentiment, as an objection it misses the aim of moral cognition. The purpose is not necessarily judgment-qua-condemnation of those who fail to meet some standard of goodness. Rather, the purpose is to understand what type of judgment-qua-social response is appropriate under the circumstances, given the relationship and other specific moral commitments we might have.

To see this, take a more serious case. Suppose that Vivian discovers that Wayne, her spouse, has had an affair; furthermore, Wayne refuses to admit to the affair, apologize, or even discuss the matter with Vivian. After engaging in the process of moral cognition, Vivian determines that the appropriate response is to seek a divorce. Vivian might reasonably say that she still cares about Wayne, wants the best for him, and respects him as a fellow human being; she has, however, determined that divorce is the morally appropriate response to Wayne's actions. Admittedly, maintaining such a positive attitude toward Wayne might be difficult, but the point is simply that Vivian's "judgment" of the appropriate response to Wayne need not entail a condemnation of Wayne. Moreover, this type of judgment is fully compatible with the notion that making an ultimate determination about whether Wayne is, all things considered, a "good" person or not is not one that mere mortals are equipped to make. What Vivian can, and should, make a judgment about is what her relationship to Wayne should be, and what response his actions and motives merit.

Finally, as a practical matter, it is hard to see how we can avoid making these kinds of judgments, nor would it be healthy in many cases to do so. We cannot, and should not, expect Joan, much less Vivian, to simply go about their lives as if nothing at all had happened. This may be possible (and desirable) in cases of very minor social conflicts, as when an inconsiderate driver cuts one off in traffic. But in cases where we suffer a cognizable harm at the hands of those we associate with, then we must determine what response is appropriate under the circumstancesand failing to do so, at least consistently, amounts to a failure to respect oneself. ${ }^{85}$

\footnotetext{
Matthew 7:1.

85 Kant memorably declares that "[b]owing and scraping before a human being seems in any case to be unworthy of a human being. . . . [And] one who makes himself a worm cannot complain afterwards if people step on him." Id. at 188 (6:437).
} 


\section{Moral Cognition in Criminal Punishment}

So far, I have explained Kant's view that humans are capable of engaging in moral cognition after condemning themselves by the operation of their consciences - and that doing so is morally required in order to respect themselves as moral agents. I then proposed that we can and should conceive of moral cognition as possible and desirable in our interactions with other people, particularly in cases where others wrong us. In this section, I suggest that moral cognition is required of good Kantian citizens who act as decision-makers in the area of criminal punishment. My comments in this section will be mostly general, and are intended to motivate the proposition that moral cognition makes sense to discuss in this context; I turn to more specific proposals in subsection D. The main goal here is to show that moral cognition does better than lex talionis alone as a principle guiding the nature and extent of punishment.

As in the previous subsection, this analysis is intended as an extension of Kant's thought, rather than a direct interpretation of it. Indeed, Kant limits his discussion of moral cognition to the context of self-knowledge. My contention, however, is that introducing this notion into the criminal justice system will be in keeping with Kant's more general commitments to justice and morality.

Moral cognition in the realm of criminal punishment may be fruitfully compared to moral cognition in the two circumstances we have already covered:

(1) In its mode of self-knowledge, moral cognition complements the operation of the conscience. Fulfilling our duties of conscience and self-knowledge are both required in order to properly respect ourselves as human beings. When we submit to the judgment of our conscience, we respect ourselves as moral agents capable of choosing in accordance with the demands of morality. When we introspectively seek self-knowledge, however, we respect ourselves as mortal beings subject to factors external to our will. Both conscience and self-knowledge are required in order to properly fulfill our duties of personal virtue with respect to ourselves.

(2) In its mode of making social judgments, moral cognition complements the operation of practical reason. Respecting other human beings requires (in certain cases) passing judgment on their actions - in doing so, we respect them as moral agents. Yet respecting others also requires cognition of their circumstances, including the most general circumstance of being subject to the conditions of mortality. A judgment tempered by moral cognition is required in order to fulfill duties of personal virtue with respect to other people.

Moral cognition in criminal punishment is both similar and different from moral cognition in the areas above. For one thing, moral cognition of the self is required by all competent moral agents - it is an inescapable duty of beings that have the capacity for moral agency. Moral cognition of other people, while not strictly necessitated by virtue of being a moral agent, is inescapable as a practical matter due to the social nature of human beings. Judgments made through the operation of the criminal law, however, are rarer. Human beings are not called upon to make 
such judgments except when required to serve as jurors or, perhaps, when making decisions about what kinds of criminal legislation to support.

Nevertheless, while the circumstances in which the moral cognition of criminals is relevant will be more limited than the previous categories, the duty will look quite similar:

(3) In its mode of judging convicted criminals, moral cognition moderates the binary judgment of the criminal law. Respecting people who have committed crimes requires punishing them, for this treats them as moral agents who could have chosen not to violate others' civic freedom. But it also requires attending to the circumstances and background conditions that contributed to the act in question. Both administering punishment and engaging in moral cognition of offenders are therefore required in order to fulfill our duties of virtue as citizens.

Virtuous Kantian citizens will, then, support policies and procedures which impose reasonable punishments that attend both to the nature of the criminal act (via lex talionis), but also to the motives and background of the criminal (via moral cognition).

It is worth thinking about the special difficulties citizens engaging in this kind of moral cognition will face. It will often require citizens to set aside their prejudices in order to reason about the needs of their community in pursuit of the ideal of justice. Most of us have no doubt experienced visceral negative responses in the face of serious criminal acts - either directed at us or at fellow human beings. Some theorists have argued that these sentiments are themselves indicia of the direction that criminal justice ought to take. ${ }^{86}$ If Kant is correct, though, then such an approach is misguided. Although these sentiments are a natural part of the human experience, they alone do not provide us with good reason to act on them. We must, rather, reason about our moral obligations in order to determine what the morally appropriate attitudes toward criminality are.

Moreover, despite his reputation as a retributivist, Kant believes that we have the duty to "[d]o good to other human beings insofar as we can ... whether [we] love[] them or not ... [and] even toward a misanthropist." ${ }^{87}$ In the face of criminal behavior, which often stirs within us understandable feelings of revulsion and vengeance, Kant would say that we retain an obligation to act benevolently, and to attempt in doing so to develop an "inclination to beneficence in general" even in the face of wrongdoing. ${ }^{88}$ Again, moral cognition in this sense is often going to be

86 See, e.g., Michael Moore, The Moral Worth of Retribution, in Punishment AND ReHABILITATION 94 (Jeffrie Murphy ed., 1995); and Jeffrie Murphy, Getting Even: The Role of the Victim, id. at 132.

87 KANT, supra note 2, at 162 (6:402).

88 Id. Virtue does not preclude us from making the necessary judgments about others' actions and responding accordingly. It does, however, require that we make such judgments in a way that is careful to distinguish what consequences another human being merits for her actions from the consequences we might initially be inclined to dispense due to our unexamined emotional responses. It might also require (or at least have the effect of) being "inclined" toward mercy rather than vengeance in the face of criminal 
challenging, just as it can be difficult in the context of our self-knowledge or our social judgments. But simplicity is not necessarily a virtue, particularly where the result of our decision-making is imposing state-sanctioned misery on fellow human beings.

\section{Specific Proposals for Moral Cognition in PUNISHMENT}

Given Kant's commitments to justice (as described in $\S \mathrm{I}$ ) and his characterization of the duty of moral cognition (as described in §II), there are good reasons to think that moral cognition must supplement lex talionis in order to determine the nature and extent of criminal punishment. In order to demonstrate how moral cognition could fulfill such a role, consider first what it means to sentence a criminal offender according to such a principle. Just as self-knowledge could increase or decrease the extent to which we punish ourselves for a specific lapse based on our character generally, a similar moral cognition applied to the convicted criminal could cause us to alter his punishment (relative to a lex talionis baseline) based on factors relevant to his background.

Thus moral cognition might simply be viewed as the type of fact-finding undertaken by a judge or jury in a sentencing hearing. A person convicted of a particular crime may be exposed to a range of possible sentences. The prosecutor often asks for a harsh penalty, the defense attorney a less severe one - and the jury makes a decision based on all the circumstances, which generally includes, not just the circumstances of the crime, but other information about the defendant's age, mental health, upbringing, and so forth. Two people who commit the same crime may, therefore, receive disparate sentences depending on how these various factors are weighed. For example, if two people are convicted of participating in the same robbery, it is possible that one co-defendant might receive a mitigated sentence (he is younger, has no criminal record, and has led a generally exemplary life until this lapse) while the other might receive an aggravated sentence (he is an older, experienced criminal with no good deeds to his name).

While one might initially think that treating people in the same way manifests an equal respect for them, some reflection should cause us to realize this is not the case. Kant himself asserts that "different forms of respect [are] to be shown to others in accordance with differences in their qualities or contingent relationsdifferences of age, sex, birth, strength, or weakness, or even rank and dignity, which depend in part on arbitrary arrangements." 89 Kant does not attempt to explain exactly how one ought to behave toward people who are "in a state of moral purity or depravity," or in "prosperity or poverty," for these are "only so many different ways of applying" the duties one owes to other people. ${ }^{90}$ He indicates, however, that determining the precise contours of one's duties toward others is an important part of one's moral obligation to respect others' humanity. ${ }^{91}$

acts. See Martha Nussbaum, Equity and Mercy, in Punishment and Rehabilitation 212 (Jeffrie Murphy ed., 1995).

89 KANT, supra note 2, at 213 (6:468).

$90 \quad$ Id. at $214(6: 468-69)$.

91 Id. 
Those involved in sentencing convicted criminals will therefore be prepared to modulate punishments depending on relevant factors. A poor person who steals bread in order to survive deserves, intuitively, a much different response from citizens of her community than the rich person who steals because she wishes to live an even more comfortable lifestyle. Of course, determining precisely how to respond to the poor thief versus the rich one will not necessarily be easy-but the civic duty of moral cognition demands that we make the attempt.

Still, one might worry about such unequal outcomes. Permitting judges and juries to consider this type of information will lead to inequities with respect to defendants' sentences. And unequal sentencing seems, in some cases, problematic. After all, a common criticism of the criminal justice system in the United States is precisely that some categories of offenders (black men in particular) receive harsher sentences than others. We might therefore be inclined, as was Kant, to endorse a strict application of lex talionis (without attendant moral cognition) out of concern for equality.

I think, however, that such an endorsement would be misplaced. It is true that troubling examples of sentencing inequities abound in our system. But so, too, do examples of defendants' sentences in ways that, while equal to others with similar convictions, are intuitively unjust given the defendant's particular circumstances. What we need to decide is whether moral cognition, with the attendant possibility of inequality, is better or worse than lex talionis standing alone.

In doing so, we should first recognize that, while Kant initially seems convinced that lex talionis alone guarantees equality, it is also true that he recognizes the impracticability in many instances of doing to the criminal exactly what she has done to the victim. ${ }^{92}$ In such cases, Kant seems to allow for consideration of the criminal's background in fashioning an appropriate punishment. For example, Kant avers that "[a] fine . . imposed for a verbal injury" would be insufficient punishment for a rich person, because he "might indeed allow himself to indulge in a verbal insult on some occasion" because of the minor cost of the criminal act. ${ }^{93}$ However, the rich man is more likely to be harmed to the same extent as one he has verbally abused if he is forced "not only to apologize publicly to the one he has insulted but also to kiss his hand . . . even though he is of a lower class." ${ }^{94}$ Apparently the fine would be an appropriate sanction for a lower-class person (because it would hurt as much as the "verbal insult" hurt the victim). Thus, despite his infatuation with lex talionis, Kant's interpretation of like-for-like punishment is not that the punishment must be identical to the crime, but that the impact on the offender must be proportional to the impact on the victim..$^{95}$

92 This would be most clearly a problem in cases of victimless crimes, though it is unclear whether Kant would recognize such a concept. As discussed earlier, Kant also recognizes the immorality of lex talionis in some cases.

93 KANT, supra note 2, at 106 (6:332).

94 Id.

95 Assuming we could come to a correct determination of what lex talionis requires in a given case, there are two interpretations: the punishment itself must be as close as possible to the criminal act, or that the punishment must result in harm to the defendant that is as close as possible to the harm caused. The former interpretation results in the literal taking of the defendant's eye when the nature of the crime is that the victim has lost an eye. The latter interpretation could conceivably result in, say, eliminating both of the defendant's eyes even though he has only destroyed one of the victim's eyes (because, 
But if we are able to take into consideration something like a person's wealth or social status in determining what his punishment ought to be, then why should we not be able to consider other factors, such as age, mental health, education, upbringing, criminal history, and so on? Surely in many (if not all) cases these factors are at least partially determinative of whether a proposed punishment would harm the defendant proportionally to the harm she has caused. Kant's example of the rich man being punished by shaming rather than fining suggests a sentencing jury may — and perhaps must - consider such factors.

Kant also makes a distinction between "punishment by a court" and "natural punishment ..., in which vice punishes itself and which the legislator does not take into account." effects brought about by substance abuse; or perhaps he is simply thinking of the pangs of guilt imposed by one's inner judge. In either case, Kant seems to be saying that whatever the "natural" consequences of one's action might be, they are separate and irrelevant to what punishment is appropriate based solely on the criminal nature of the act. Kant thus says that the legislator cannot consider natural punishment, and this makes some sense: statutory law proscribes certain conduct and affixes a proportional punishment to it, but is generally not concerned with specifics about a criminal's circumstances.

Kant does not explain, though, why courts may not appropriately consider "natural punishment" when using their discretionary authority to pronounce sentence in a specific case. Doing so would have the same effect as if a drug addict were to sentence herself to misery because of her choice to indulge in a narcotic, yet acknowledge that her life has already been turned upside down by her addiction. This self-knowledge might cause the addict to decide to focus on rehabilitation rather than further self-punishment. Likewise, the sentencing judge or jury might reasonably decide that the convicted addict has suffered enormously already and needs a sentence that involves more rehabilitation and less imprisonment. This vision of the sentencer's role makes sense if it is seen as responsible for using moral cognition to fashion an appropriate response to a criminal defendant that treats her as a free, equal, and independent moral agent — not merely as a wrongdoer.

Finally, another interpretation of Kant's approval of lex talionis suggests that "the law cannot assess the 'inner' moral worth of offenders because that would require knowing more about the agent's motives and 'will' than we can determine

say, the victim only had one eye to begin with; or because the victim is a child forced to live with one eye for the rest of her life, while the defendant has had the luxury of living an already long life with two eyes). Kant seems to favor the second interpretation at least in the case of the rich man who has insulted the lower-class citizen. He does not explain clearly why this is the case, however. These could result in considerably different consequences: the impact of a given sentence is almost sure to have a highly variable impact depending on both the defendants' and victims' circumstances. If it is correct that Kant countenances this version of lex talionis, this does not necessarily mean that Kant would agree with mitigation based on the defendant's character or circumstances. But if we are going to consider aggravation based on circumstances (the rich man gets a more significant, public penalty than the poor man) then surely we ought also to consider mitigation as well (e.g. the pauper who insults the rich man might also receive a different sentence than a fine, because this would be a catastrophic penalty grossly disproportionate to the harm caused). 
with confidence." ${ }^{97}$ We ought to be skeptical of such a claim, even if Kant believed it. For one thing, the law does do this, and has for centuries. Proving mens rea is essential to demonstrating that a crime actually occurred. The alleged criminal found to lack the right state of mind - the necessary motive or will-must, in theory, be set free. This is, admittedly, not an easy task in all cases. Moreover, while "moral worth," in any deep, meaningful sense, is not what the criminal justice system attempts to discern, sentencing courts (good ones, anyway) do attempt to gather as much information about the circumstances surrounding the defendant's crime as possible before imposing judgment. It may be that such determinations are often flawed - but certainly we should try, insofar as we are able, to distinguish between those who commit crimes for motives of profit and those who do so out of desperation; between those who harm others out of spite and those who do so out of ignorance; and between those who are fully cognizant of their options and those who have limited capacities for such introspection. Again, these are not always simple decisions, and when made properly, they may not serve the interests of "judicial economy." But we know from our inner moral lives that they are necessary and relevant considerations when assessing wrongdoing. They therefore seem equally vital in assessing the proper punishment for offenders.

It would appear, then, that even Kant's own view of punishment is more flexible than it first appears. Even if it were not, Kant's own commitment to equality, which underwrites his endorsement of lex talionis, militates in favor of more flexible sentencing policies. Equality in a Kantian sense does not imply that we should punish all criminals in the same way. Rather, it implies that we ought to attempt to tailor a defendant's sentence to take into account his background as well as his motives and intentions. Despite Kant's thoughts to the contrary, lex talionis on its own seems destined to fail in realizing a full conception of Kantian equality.

This is sufficient to show that moral cognition needs to supplement lex talionis in making decisions about the nature and extent of punishment. I think, however, that the principle of moral cognition can do more. I shall therefore proceed to give several brief examples of ways in which developing this virtue can assist us in crafting more just criminal policies..$^{98}$

First, we must ensure that a criminal's punishment is decent and humane - - "free[] from mistreatment," as Kant puts it ${ }^{99}$ - in order to respect her status as a human being. Kant believes that the virtue of our society, and our freedom as citizens, depends largely on the way in which we treat our fellow citizens - including those who are being punished for wrongdoing. There is a stark difference between being deprived of liberty for ten years, and being subjected to a violent nightmare for the same period of time. Unfortunately, the latter is closer to the reality in many American prisons. ${ }^{100}$ Certainly an increased moral cognition of the plight of convicted criminals would encourage mostly stagnant efforts toward prison reform. ${ }^{101}$

\footnotetext{
97 Hill, supra note 18 , at 429.

98 Once again, I intend these examples to be construed as reasonable derivations from Kantian principles. Kant himself does not necessarily endorse them-indeed, he has almost nothing to say about criminal justice policies at this level of detail.

99 KANT, supra note 2, at 106 (6:333).

100 Douglas Husak, Overcriminalization: The Limits of The Criminal Law 5-6 (2008).

101 See generally Sarah Holtman, A Kantian Approach to Prison Reform, 5 JAHRBUCH FÜR RECHT und ETHIK 315 (1997).
} 
Second, we can focus more attention on how we treat convicted criminals postconviction and post-incarceration. Ideally, one of the things we do as moral beings who seek self-knowledge after an act of wrongdoing is to carefully attend to whatever conditions precipitated our action. We may find it necessary to spend time or resources to change something about ourselves or our situation in order to prevent subsequent misbehavior. Similarly, we ought to treat the convicted criminal in a way that reflects his status as a citizen as well as the specific background circumstances that might have contributed to the crime. Sometimes these circumstances call into question a citizen's capacity for independence, as may be the case with serious mental illnesses. Other times we may recognize a failure of civic equality and substantive freedom when, for example, the defendant has grown up in an impoverished community and has lacked access to basic resources and social goods such as education.

This is not to say that we ought not to punish offenders where appropriate. Punishment can be a way of recognizing a defendant's capacity for moral autonomy. It can, however, also be an opportunity to address regrettable injustices that have made the defendant's choices more difficult than they would have been in an ideally just society. Thus, while we have a duty to punish the criminal, we ought also to recognize a duty to discover his needs and attend to them, much as we might rightly experience emotional pain after doing something morally repugnant, but also muster enough self-knowledge to realize that we need something more than punishment (perhaps, for example, we need counseling to help us confront whatever demons are encouraging our moral misbehavior).

So even if we were to agree that, say, five years in prison were the appropriate response for an aggravated assault, after imposing that sentence we might have the continuing duty to offer services to the criminal, both during and after incarceration. Obvious examples of such services are mental health treatment, anger management counseling, education, and job training - whatever is necessary to help the person overcome circumstances contributing to the criminal act. We do this to some extent in our current system, but to an insufficient extent. Probation and parole are usually either overly onerous (resulting in inevitable violations and re-incarceration) or too lax (a lack of structure and assistance frequently resulting in recidivism and, again, re-incarceration). Part of the reason is, perhaps, that the rehabilitative model of criminal justice that was popular in the first half of the twentieth century has been largely abandoned. While there may be good reasons to distrust a purely "medical model" of criminology, ${ }^{102}$ surely rehabilitation ought to play a more distinctive role in our system than it currently does. This is particularly clear in the case of drug crimes, where imprisonment is, at best, unlikely to result in the changes within the individual which are necessary in order to prevent recidivism. Some jurisdictions are experimenting with "drug court" and similar diversion programs, with anecdotally positive results.

Third, we need to educate the average American about what criminal justice really entails. The tendency in American society is to view convicts with anger, fear, and contempt. We assume that people who commit crimes will do so again - and, as if to ensure that such prophecies are realized, we refuse to offer them the services and support that would maximize their chances for successful reintegration into society.

102 See generally Herbert Morris, Persons and Punishment, in Punishment AND Rehabilitation 74 (Jeffrie Murphy ed., 1995). 
At one time, the ostensible purpose of "penitentiaries" was what the root of the word implies: to encourage penitence and character reformation. ${ }^{103}$ Theoretically, people who emerged from such facilities were changed and ready to be welcomed back into the community. Instead, we now relegate criminals to facilities that are nearly certain to encourage, rather than dispel, whatever criminal intentions they arrive with. Clearly, "[t]reating offenders as worthless scum, utterly incapable of reform, is obviously contrary to Kantian principles." 104 It is in keeping with the spirit of the Kantian moral law that we ought to treat people convicted of crimes better than we do. This must include recognizing their intrinsic worth, their adverse backgrounds, and their potential for progress - just as we recognize such factors when viewing ourselves with properly objective self-knowledge. Moreover, since the American public seems to think that prisoners have it too easy, education both about what conditions are like inside prisons, as well as what factors often contribute to criminal behavior, would be useful ways of increasing our collective moral cognition in this sphere. Doing so would serve the ends of Kantian justice, by promoting the civic equality and independence that would, in turn, make criminal violations of the UPR less likely to recur.

Related to this is my fourth and final point: we need to work toward replacing the retributive ethos that characterizes American criminal justice with something more Kantian. I return once more to Kant's moral theory to show what I mean. Once we have condemned ourselves, via our conscience, for having acted wrongly, our subsequent moral cognition surely entails that we do not give up on ourselveswe respect ourselves as competent moral agents capable of repentance and worthy of redemption. ${ }^{105}$ Kant asserts that moral cognition will "dispel fanatical contempt" for ourselves. ${ }^{106}$ Though self-punishment (misery) is appropriate and necessary when we violate the moral law, moderation in self-perception through the process of cultivating self-knowledge is also necessary. While moral failures ought to involve a period of psychic self-flagellation, they ought not to induce self-hatred.

In the social context, one of the vices that Kant mentions in the Tugendlehre is "malice," which he characterizes as "the direct opposite of sympathy."107 Significantly, Kant addresses in his discussion of malice the propensity which human beings experience toward vengeance:

The sweetest form of malice is the desire for revenge. Besides, it might even seem that one has the greatest right, and even the obligation (as a desire for justice), to make it one's end to harm others without any advantage to oneself. ... But punishment is not an act that the injured party can undertake on his private authority $\ldots 0^{108}$

\footnotetext{
103 David J. Rothman, The Discovery of The Asylum: Social Order and Disorder iN THE New Republic 79 (rev. ed., Aldine Transaction, 2002).

104 Hill, supra note 18, at 439.

105 This is perhaps one reason Kant speaks so forcefully against suicide. Kant, supra note 2 , at $176-78(6: 422-23)$.

106 Id. at $191(6: 441)$.

107 Id. at $207(6: 459)$.

$108 I d$. at 207 (6:460) (emphasis in original).
} 
Except in the case of punishment properly administered by a civil authority, acts of vengeance (even though seemingly "the greatest right") are permissible only to God - the rest of us have "a duty of virtue not only to refrain from repaying another's enmity with hatred out of mere revenge but also not even to call upon the judge of the world for vengeance." 109

As Kantian citizens, then, one duty we incur by virtue of our status as moral beings is to refrain from punishing those who wrong us - another is to refrain from endorsing appropriate state punishment from motives of vengeance. This, in turn, provides us with some understanding of the way in which punishment is to be administered in a just society: "no punishment, no matter from whom it comes, may be inflicted out of hatred." ${ }^{110}$ Criminal punishment must not be confused, in other words, with state-sanctioned vengeance. The former is an appropriate way for the community to demonstrate that certain types of behavior are unacceptable by its citizens; the latter is merely the institutionalization of malice.

To such a way of thinking about punishment, one might worry that there are at least some crimes which merit, if not demand, an attitude of vengeance. ${ }^{111}$ Is it really the case that we should seek to cultivate a dispassionate attitude toward, say, serial killers or child rapists? It is surely true that humanity's capacity for evil in some cases demands moral outrage. But it is worth considering how outrage, anger, and indignation differ from vengeance, hatred, and malice. For one thing, the former feelings are compatible with forgiveness, mercy, and sympathy, while the latter are not. The former may also be directed toward ideas - one is indignant that a human being could behave in such-and-such a way-while the latter seem inevitably directed at a person or group - one seeks revenge on someone, or hates people like that. Kant's point is not, I think, that punishment should be entirely devoid of emotion. Rather, it is that punishment ideally involves certain kinds of publicly appropriate reactions to offenses but does seek to limit the extent to which we utilize punishment as a vehicle for satisfying our animalistic lust for revenge.

One of the concerns that might be raised here is the possibility of becoming too "soft." If a person exhibits no response whatsoever to any sort of wrong inflicted on her, we might worry that she is being taken advantage of - that she is failing to exercise the self-respect that is sometimes manifested by the behavior of identifying and objecting to a wrong. Kant does address such an objection, though, when he notes that although "[i]t is therefore a duty of human beings to be forgiving . . . this must not be confused with meek toleration of wrongs ... [nor with the] renunciation of rigorous means ... for preventing the recurrence of wrongs by others; for then a human being would be throwing away his rights and letting others trample on them, and so would violate his duty to himself." 112 Restraining oneself from exercising punishment, and endeavoring to act non-maliciously, does not mean that we should not assert our rights, where appropriate, or act in ways disrespectful of our own autonomy. We should surely not stay in an abusive relationship - but we can let

$109 \quad I d$. at $208(6: 460)$.

$110 I d$. at $208(6: 461)$.

111 For such a view, see Moore, supra note 86.

112 KANT, supra note 2, at 208 (6:461) (emphasis in original). 
others do the punishing, and work toward forgiveness, but for the sake of the abuser and ourselves. ${ }^{113}$

Kantian morality therefore demands a fine balance in responding to crime. On the one hand, we must respect ourselves (and, by extension, our fellow-citizens) enough to stand against, and be willing to punish via appropriate authorities, criminal wrongdoing. On the other hand, we must strive to replace feelings of malice, hatred, or vengeance that we might experience with more productive sentiments that preserve our respect for the dignity of others. In doing so, we contribute to a more just society and, equally important for Kant, to our own moral development.

Here are three preliminary suggestions that aim at moral cognition in this area. First, scholars and jurists need to devote more energy toward educating the public about the connections between criminality on the one hand and socioeconomic privations on the other. Although we should not overstate such correlations, we must recognize that there is at least some responsibility that we bear collectively as citizens for permitting the social conditions to exist that foster criminal behavior. ${ }^{114}$

Second, we should also ensure that convicts' voting rights are maintained even during their period of incarceration. There are many rights which convicts reasonably forfeit for a period of time upon conviction - the right to travel, the right to own a firearm, and so on - but there is no compelling reason to prevent them from voting. The right to vote is the most basic right we can accord citizens, and while allowing criminals to vote harms no one, it is a small but symbolically significant step in the direction of conceiving of them as (punishable) fellow-citizens, rather than as outcasts. ${ }^{115}$

Third, we should follow some European countries' practice of viewing criminal convictions as private (or quasi-private) records, which in turn discourages discrimination in areas such as employment and housing on the basis of prior criminal behavior. ${ }^{116}$ Allowing people who have "served their time" to return to as normal a life as possible would encourage others to view them in a way that respects their status as free, equal, and independent fellow-citizens.

113 As Kant puts it, "a human being . . . possesses a dignity (an absolute inner worth) by which he exacts respect for himself from all other rational beings in the world." Id. at 186 (6:434-35) (emphasis in original).

114 For an argument to this end, see David L. Bazelon, The Morality of the Criminal Law, 49 S. CAL. L. Rev. 385 (1976). Stephen J. Morse provides a response in The Twilight of Welfare Criminology: A Reply to Judge Bazelon, 49 S. CAL. L. Rev. 1247 (1976). Bazelon does, I think, overstate the case; nevertheless, his essay is a powerful antidote to the tendency to ignore social factors in attempting to understand and respond to criminal behavior.

115 It may turn out that permitting inmates to vote would do significantly more than this, since African-American communities may be disproportionately affected in terms of democratic representation by the incarceration of such a large percentage of their members. See, e.g., Dorothy E. Roberts, The Social and Moral Cost of Mass Incarceration, in African American Communities, 56 Stan. L. Rev. 1271 (2004).

116 See generally James B. Jacobs \& Elena Larrauri, Are Criminal Convictions a Public Matter? The USA and Spain, 14 Punishment AND Soc'y 3 (2012). Obviously there would need to be exceptions. Someone convicted of child abuse might reasonably be barred from working as a school teacher, but there is likely no good reason to prevent him from taking up a career in accounting. 
These three suggestions are hardly the end of the story; they constitute merely preliminary thoughts about the way the notion of moral cognition could be deployed to counteract the lamentable retributive ethos that characterizes Anglo-American punishment practices.

\section{LAWYERLY OBJECTIONS}

In the course of the preceding argument, I addressed a number of theoretical objections. Legal professionals, however, might also raise some legitimate pragmatic concerns. In particular, defense attorneys and prosecutors might worry that the concept of moral cognition could be detrimental to the interests they are ethically bound to protect.

The defense bar might be concerned about the possibility of moral cognition resulting in harsher sentences for criminal defendants. In many cases lawyers advise clients to enter plea agreements in order to reduce the risks and uncertainties of trial and subsequent sentencing hearings where a terrifyingly wide range of options may be open to the judge. To demand the moral cognition of each individual defendant invites judges or juries to punish some people more harshly than they would be able to do given the way the system works currently.

It is undeniable that moral cognition will sometimes incline us towards increasing punishment. Just as we sometimes reflect on our own actions and realize that we behaved in some way worse than we might initially have judged, so it is likely that some criminals are in fact deserving of harsher punishment than we initially think - though in no case could the upper limitation of lex talionis be exceeded. I suspect, however, that this is unlikely to be the outcome in the majority of cases. This is suggested by Martha Nussbaum, who has argued for an increase in mercy within the criminal justice system by way of the ancient Greek concept of epieikeia, which she explains as "the ability to judge in such a way as to respond with sensitivity to all the particulars of a person and situation, and the "inclination of the mind' toward leniency in punishing - equity and mercy." 117 She believes that while the "retributive idea is committed to a certain neglect of the particulars,"118 the practice of epieikeia is "a gentle art of particular perception, a temper of mind that refuses to demand retribution without understanding the whole story." 119 Nussbaum's contention is that an increased moral cognition, as Kant would say, almost always leads us to "see[] defendants as inhabitants of a complex web of circumstances, circumstances which often, in their totality, justify mitigation of blame or punishment." 120

On the other hand, those who prosecute criminal cases might not see such an outcome as desirable. Some prosecutors might worry that an increase in moral cognition will result in too little punishment - that wrongdoers will "get away with murder" based on circumstances (poverty, abuse, and so on) shared by many noncriminals. More broadly, we might be concerned that, if moral cognition in fact generally inclines us toward mercy, such an approach negates the importance of

117 See Nussbaum, supra note 88, at 214.

$118 \quad I d$. at 217.

$119 \quad I d$. at 219.

120 Id. at 235-36. 
personal responsibility and minimizes the deterrent potential of the criminal law. Although I have less sympathy for this view, given the excessively harsh nature of criminal justice in our society, it is worth remembering that "[m]ercy is not acquittal." 121 Kant certainly agrees that wrongdoing must be punished - and that this is true both at the level of personal morality and within civil society. Moral cognition does not "fail to say that injustice is injustice, evil is evil." 122 It may, however, result in most cases in a more merciful and understanding approach to punishing those who violate our laws. To this extent, the prosecutor's concern is well-founded: a system imbued with increased moral cognition will very likely result in shorter prison terms and fewer death sentences, among other consequences. I do not find this to be an objectionable result, particularly in the context of our current criminal penal practices.

The skeptical lawyer might still be shaking his or her head. Criminal justice in the real world is a messy business, and the suggestion that moral cognition ought to play a role in our penal practices is unrealistic. The skeptic has a point. Kant acknowledges the difficulty of moral cognition in its personal incarnation of selfknowledge, saying that "the depths . . . of one's heart . . . are quite difficult to fathom"; still, he is confident that the attempt to do so is "the beginning of all human wisdom." 123 Attempting to engage in moral cognition in the context of criminal justice will be equally difficult. Doing so will, however, result in penal practices that are similarly wiser — and more just — than our current ones.

$121 \quad I d$. at 247.

122 Id.

123 KANT, supra note 2, at 191 (6:441). 